\title{
Detergent Properties of Coconut Oil Derived N-Acyl Prolinate Surfactant and the In silico Studies on its Effectiveness Against SARS-CoV-2 (COVID-19)
}

In this work, we report the application of coconut oil derived Nacyl prolinate surfactant as a potential ingredient in laundry detergent formulation using biological, physicochemical and molecular docking approach. The properties of the sodium cocyl prolinate surfactant $\mathbf{2}$ were compared with those of sodium cocoate surfactant 1, a sodium salt of fatty acids from coconut oil, as well as the conventional surfactant sodium dodecyl sulphate (SDS) which is commonly used in the detergent industry. Sodium cocyl prolinate surfactant $\mathbf{2}$ showed a lower foaming ability compared to SDS and was found to exert a better detergency at a much lower temperature $\left(25^{\circ} \mathrm{C}\right)$ compared to surfactant 1 and SDS. The coconut oil based surfactants $\mathbf{1}$ and $\mathbf{2}$ displayed a better antibacterial activity against gram positive strains compared to SDS. In view of studying the effectiveness of the surfactants against the severe acute respiratory syndrome corona virus 2 , SARS-CoV-2 (COVID-19) which might remain on the surface of contaminated clothes, molecular docking of surfactants $\mathbf{1}$ and $\mathbf{2}$ with the spike protein of SARS-CoV-2 was carried out. Surfactant $\mathbf{2}$ showed an optimum interaction with the amino acid residues of the spike protein which is responsible for the binding of the virus with the host receptors. Molecular docking with savinase, an enzyme used in laundry formulation showed that sodium cocyl prolinate surfactant 2 and SDS displayed comparable interactions with the enzyme. Overall, this study has shown that sodium cocyl prolinate surfactant $\mathbf{2}$ can be a potential candidate in laundry detergent formulation for machine washing due to its relatively low foaming ability and good detergency properties at a much lower temperature $\left(25^{\circ} \mathrm{C}\right)$, making it more energy-efficient. Surfactant $\mathbf{2}$ was also found to be a promising antimicrobial agent in laundry detergent due to its moderate antibacterial activity and its interaction with the spike protein of SARS-CoV-2, which can help to reduce the spread of any epidemic or pandemic diseases.

Key words: Sodium cocyl prolinate, coconut oil, foaming ability, antibacterial activity, detergency, molecular docking, spike protein of SARS-CoV-2, savinase enzyme

Wascheigenschaften eines aus Kokosnussöl abgeleiteten $\mathbf{N}$-Acyl-Prolinat-Tensids und In-silico-Studien über seine Wirksamkeit gegen SARS-CoV-2 (COVID-19). In dieser Arbeit berichten wir über die Anwendung des aus Kokosnussöl gewonnenen N-Acylprolinat-Tensids als potenziellen Inhaltsstoff in Waschmittelformulierungen unter Verwendung eines biologischen, physikalisch-chemischen und molekularen Docking-Ansatzes. Die Eigenschaften von Natrium-Cocylprolinat-Tensid 2 wurden mit denen von Natrium-Cocoat-Tensid 1, einem Natriumsalz von Fettsäuren aus Kokosnussöl, sowie mit dem her- kömmlichen Tensid Natriumdodecylsulfat (SDS), das in der Waschmittelindustrie häufig verwendet wird, verglichen. Natrium-Cocylprolinat-Tensid $\mathbf{2}$ zeigte im Vergleich zu SDS ein geringeres Schäumvermögen und im Vergleich zu Tensid $\mathbf{1}$ und SDS bei einer viel niedrigeren Temperatur $\left(25^{\circ} \mathrm{C}\right)$ eine bessere Waschleistung. Die auf Kokosnussöl basierenden Tenside $\mathbf{1}$ und 2 zeigten im Vergleich zu SDS eine bessere antibakterielle Aktivität gegen grampositive Stämme. Im Hinblick auf die Untersuchung der Wirksamkeit der Tenside gegen das schwere akute respiratorische Syndrom Coronavirus 2, SARS-CoV-2 (COVID-19), das auf der Oberfläche kontaminierter Kleidung verbleiben könnte, wurde das molekulare Andocken der Tenside 1 und $\mathbf{2}$ an das Spike-Protein von SARS-CoV-2 durchgeführt. Tensid 2 zeigte eine optimale Interaktion mit den Aminosäureresten des Spike-Proteins, das für die Bindung des Virus an die Wirtsrezeptoren verantwortlich ist. Molekulares Andocken mit Savinase, einem Enzym, das in der Waschmittelformulierung verwendet wird, zeigte, dass Natrium-Cocylprolinat-Tensid 2 und SDS vergleichbare Wechselwirkungen mit dem Enzym zeigten. Insgesamt hat diese Studie gezeigt, dass das Natrium-CocylprolinatTensid $\mathbf{2}$ aufgrund seines relativ geringen Schaumvermögens und seiner guten Waschleistung bei einer viel niedrigeren Temperatur $\left(25^{\circ} \mathrm{C}\right)$ ein potenzieller Kandidat einer Waschmittelformulierung für die Waschmaschine sein kann, was es energieeffizienter macht. Tensid $\mathbf{2}$ erwies sich auch als vielversprechendes antimikrobielles Mittel in Waschmitteln aufgrund seiner moderaten antibakteriellen Aktivität und seiner Wechselwirkung mit dem Spike-Protein von SARS-CoV-2, das dazu beitragen kann, die Ausbreitung von Epidemien oder pandemischen Krankheiten einzudämmen.

Stichwörter: Natrium-Cocylprolinat, Kokosnussöl, Schäumungsfähigkeit, antibakterielle Aktivität, Detergenz, molekulares Andocken, Spike-Protein von SARS-CoV-2, Savinase-Enzym

\section{Introduction}

Soap and detergent production is a well-established technology that is making enormous advances towards developing more effective formulations that meet consumer needs [1]. Laundry detergents, which are used in various areas of daily life and in industry, consist of several ingredients, including surfactants. The latter play a vital role in cleaning and removal of stains and account for almost $15 \%-40 \%$ of the detergent formulations [2, 3]. Surfactants have been known to enhance the detergency by lowering the interfacial tension between the fabric and stains by mechanisms such as emulsification and solubilisation, which eventually leads to the stain removal $[4,5]$. The use of anionic surfactants such as sodium 
lauryl sulphate as active ingredients in laundry products is well documented [6-8].

Apart from the cleaning and stain removal actions, the antimicrobial properties of laundry detergent formulations are important requirements that need to be addressed. Clothes often carry a certain amount of moisture, which makes the clothes susceptible for the breeding of bacteria and viruses. The recent emergence of Wuhan severe acute respiratory syndrome coronavirus 2, SARS-CoV-2 (COVID-19) which is similar to the virus caused by severe acute respiratory syndrome coronavirus (SARS-CoV), has put the world on alert on the mode of transmission of the virus. Although the SARS-CoV-2 is mostly airborne, the virus can also spread from one person to another via contaminated surfaces such as clothes on which the virus can remain viable for several hours to maybe a day. Hence, the use of laundry detergents containing surfactants with antimicrobial activities ensures that the clothes are clean and free from microbes that are able to harm the health of the population.

With the rising recognition for the need to preserve the environment, the development of surfactants which are less toxic to the marine environment as well as having good biodegradability and ecological compatibility has become the main focus of the surfactant detergent industry [9]. There has been growing attention towards the synthesis of surfactants derived from natural resources as potential substitutes for petroleum based surfactants.

Amino acid-based surfactants have emerged as an alternative due to their good biocompatibility, multifunctional properties as well as being mild and almost harmless to aquatic organisms [10-13]. Among the different surfactants reported, $\mathrm{N}$-acyl amino acid based surfactants have been given particular attention due to their good foaming ability, antimicrobial properties, antistatic abilities, good surface activities and being considered as environmentally friendly products $[14,15]$. $N$-cocoyl-L-glutamate and potassium $N$-cocoyl glycinate, have applications in cosmetics and N-acyl surfactants derived from phenylalanine and leucine have been known for their good detergency and foaming properties [16]. $N$-acyl derivatives of proline are known to play a significant role by acting as hydrogen bond acceptor in the binding to target proteins, namely enzymes [17], making them important in many applications including detergency. Recently, our group reported a series of proline based surfactants, which showed good foaming and antibacterial activities as both single and mixed surfactant systems, making them promising candidates in detergent formulations [18].

Sodium $N$-acyl prolinate surfactants derived from coconut, palm, karanja, Sterculia foetida and high oleic sunflower oils have been reported to exhibit superior surface active properties, calcium tolerance and emulsion stability as compared to the standard surfactant, sodium dodecyl sulphate [19, 20]. To the best of our knowledge, there has been no report on the detergency properties of sodium $\mathrm{N}$-acyl prolinate surfactants.

In the present study, coconut oil derived surfactants, namely sodium cocoate surfactant 1 and sodium cocyl prolinate surfactant 2 were synthesised and assessed for their physicochemical and detergency properties and compared with the conventional surfactant SDS. In view of studying the effectiveness of the surfactants as promising antimicrobial ingredient in detergent formulation, the antibacterial properties of the synthesised surfactants were determined. Molecular docking of the surfactants with spike protein of SARS-CoV-2 was carried out in order to study their efficiency in reducing the spread of corona virus which can remain on the surface of clothes for hours. Their interactions with the detergent enzyme Savinase was also investigated using molecular docking studies in order to study whether the surfactant and enzyme can both exert their action synergistically without denaturing the enzyme and hence their potential use in washing powder formulations.

\section{Materials and Methods}

\subsection{Chemicals and instrumentations}

L-Proline was purchased from Himedia laboratory, triethylamine (TEA), dimethyl-amino pyridine (DMAP) and dodecanoic acid were from Sigma Aldrich (USA). Sodium dodecyl sulfate (SDS) and thionyl chloride were obtained from Loba Chemie (India). Virgin coconut oil was obtained from Agalega, a small island in the Indian Ocean under the territory of Mauritius, and was used without further purification. Other materials and reagents were used as received.

${ }^{1} \mathrm{H}$ and ${ }^{13} \mathrm{C}$ NMR spectra were recorded at $250 \mathrm{MHz}$ and 62.9 MHz on a Bruker electro spin NMR spectrometer using $\mathrm{D}_{2} \mathrm{O}$ as solvent. IR spectra were recorded on a Bruker Alpha FT-IR spectrophotometer. Conductivity measurements were obtained using a Jenway 4320 conductivity meter. ACCDYER - 18 lab dyeing machine of speed $0-50 \mathrm{rpm}$ was used for the detergency testing. The datacolor high performance benchtop spectrophotometer (Datacolor $650^{\mathrm{TM}}$ ) equipped with multiples aperture sizes to accommodate samples of different sizes were used to determine the reflectance of the swatches.

\subsection{Chemical profile}

Virgin coconut oil (0.05 g) was hydrolyzed using methanolic potassium hydroxide $(1 \mathrm{~mL}, 2 \mathrm{M})$ in hexane $(10 \mathrm{~mL})$ and the chemical profile analysis of the coconut oil was conducted using Gas Chromatography (GC). The GC analysis was performed using a Shimadzu GC 2010 coupled with mass spectrometry with a column specification SPTM-2560 (100 m length, diameter: $0.25 \mathrm{~mm}$, thickness: 0.20 micron) with an injection and detector temperature of $260^{\circ} \mathrm{C}$ and $280^{\circ} \mathrm{C}$ respectively. Helium having a flow rate of $1 \mathrm{~mL} / \mathrm{min}$ was used as the carrier gas.

\subsection{Synthesis of sodium cocoate surfactant 1}

Virgin coconut oil (7.04 g, $35.18 \mathrm{mmol})$ was hydrolysed with equimolar amount of $\mathrm{NaOH}(1.46 \mathrm{~g}, 36.44 \mathrm{mmol})$ in methanol $(10 \mathrm{~mL})$ for $1 \mathrm{~h}$ at room temperature. The organic solvent excess was removed under vacuo to obtain the sodium salts of the coconut fatty acids.

Yield $=90 \%$. IR $\left(v_{\max }, \mathrm{cm}^{-1}\right): 2920,2848\left(v_{\mathrm{C}-\mathrm{H}}\right), 1557$ $\left(v_{\mathrm{C}=\mathrm{O}}\right.$, assym $\left.\mathrm{COO}^{-}\right), 1444\left(v_{\mathrm{C}=\mathrm{O}}, \operatorname{sym} \mathrm{COO}^{-}\right) .{ }^{1} \mathrm{H}$ NMR $\left(\mathrm{D}_{2} \mathrm{O}\right): \delta \mathrm{ppm}=0.73\left(\mathrm{CH}_{3}, \mathrm{t}, J 6.50 \mathrm{~Hz}\right) ; 1.16\left(\left(\mathrm{CH}_{2}\right)_{\mathrm{n}}, \mathrm{m}\right)$; 1.38-1.44 ( $\left.\mathrm{CH}_{2}, \mathrm{~m}\right) ; 2.00-2.07\left(\mathrm{CH}_{2}, \mathrm{t}, J 7.50 \mathrm{~Hz}\right) .{ }^{13} \mathrm{C} \mathrm{NMR}$ $\left(\mathrm{D}_{2} \mathrm{O}\right): \delta \mathrm{ppm}=13.4\left(\mathrm{CH}_{3}\right) ; 22.0-31.0\left(\mathrm{CH}_{2}\right)_{\mathrm{n}} ; 31.4\left(\mathrm{CH}_{2}\right)$; 37.7 $\left(\mathrm{CH}_{2}\right) ; 184.1(\mathrm{C}=\mathrm{O})$.

\subsection{Synthesis of sodium cocyl prolinate surfactant 2}

The fatty acid mixtures present in coconut oil (10.17 g) were dissolved in dry dichloromethane (DCM, $20 \mathrm{~mL}$ ) and stirred with excess thionyl chloride $(4.00 \mathrm{~mL}, 55.14 \mathrm{mmol})$ for $3 \mathrm{~h}$ at $40{ }^{\circ} \mathrm{C}$. The coconut mixed fatty acid chlorides $(10.58 \mathrm{~g}$, $48.36 \mathrm{mmol}$ ) were obtained by distilling out of thionyl chloride excess under vacuo. The mixture of the freshly prepared coconut fatty acid chlorides was added dropwise to a solution of proline $(5.64 \mathrm{~g}, 49.02 \mathrm{mmol})$ in THF $(50 \mathrm{ml})$ in the presence of TEA and a catalytic amount of DMAP. The reaction mixture was refluxed for $18 \mathrm{~h}$ at $70^{\circ} \mathrm{C}$. The reaction was 
quenched with distilled water $(100 \mathrm{~mL})$ and the product was extracted with ethyl acetate $(4 \times 50 \mathrm{~mL})$. The organic extract was washed with aqueous sodium hydrogen carbonate $(5 \%$, $50 \mathrm{~mL}$ ) and dried with anhydrous sodium sulfate. The organic solvent excess was removed under vacuo to yield a viscous oily liquid. The oily liquid $(1.29 \mathrm{~g}, 6.45 \mathrm{mmol})$ was stirred with $\mathrm{NaOH}(1.46 \mathrm{~g}, 36.44 \mathrm{mmol})$ in methanol for $1 \mathrm{~h}$ at room temperature. The methanol was then removed under vacuo to obtain the desired product as a solid $(1.20 \mathrm{~g}, 83.6 \%$ yield)

Yield $=78 \%$. IR $\left(v_{\max }, \mathrm{cm}^{-1}\right): 2919,2851\left(v_{\mathrm{C}-\mathrm{H}}\right), 1616$ $\left(v_{\mathrm{C}=\mathrm{O}}\right.$, amide) $1559\left(v_{\mathrm{C}=\mathrm{O}}\right.$, assym $\left.\mathrm{COO}^{-}\right), 1444\left(v_{\mathrm{C}=\mathrm{O}}\right.$, sym $\left.\mathrm{COO}^{-}\right) .{ }^{1} \mathrm{H}$ NMR $\left.\left(\mathrm{D}_{2} \mathrm{O}\right): 0.72-0.73\left(\mathrm{CH}_{3}\right) ; 1.14\left(\mathrm{CH}_{2}\right)_{\mathrm{n}}, \mathrm{m}\right)$; 1.40-1.43 $\left(\mathrm{CH}_{2}\right) ; 1.74-1.82\left(\mathrm{CH}_{2}, \mathrm{~m}\right) ; 1.99-2.09\left(\mathrm{CH}_{2}, \mathrm{~m}\right)$; $3.31-3.41$ (2H, m); $4.09-4.21$ (1H, d, J $0.58 \mathrm{~Hz}) .{ }^{13} \mathrm{C}$ NMR $\left(\mathrm{D}_{2} \mathrm{O}\right): \delta \mathrm{ppm}=13.9\left(\mathrm{CH}_{3}\right) ; 22.6-34.5\left(\mathrm{CH}_{2}\right)_{\mathrm{n}} ; 37.9\left(\mathrm{CH}_{2}\right)$; $47.8\left(\mathrm{CH}_{2}\right) ; 61.6(\mathrm{CH}) ; 173.8(\mathrm{C}=\mathrm{O}) ; 179.7(\mathrm{C}=\mathrm{O})$.

\subsection{Physicochemical Parameters}

\subsubsection{Critical micelle concentration (CMC)}

The critical micelle concentration (CMC) of the surfactants 1 and 2 were determined in deionized water at $25^{\circ} \mathrm{C}$ using the method previously reported by our group [21].

\subsubsection{Krafft temperature}

The Krafft temperature of the sodium cocoate surfactant 1 and sodium cocyl prolinate surfactant 2 were determined using the conductivity method [22]. Solutions of each surfactant $(10 \mathrm{~mL}, 0.1 \mathrm{M})$ in deionized water were kept at $4.0^{\circ} \mathrm{C}$ for $24 \mathrm{~h}$ and the conductivity of the solutions after each temperature rise of $0.5^{\circ} \mathrm{C}$ was recorded.

\subsubsection{Foaming capacity and foaming stability}

The foaming capacity and stability of the sodium cocoate $\mathbf{1}$ and the sodium cocyl prolinate surfactant 2 were determined by manual shaking of solutions $(10 \mathrm{ml}, 0.01 \mathrm{M})$ in a sealed measuring cylinder for $60 \mathrm{~s}$. The solutions were left to stabilize for $10 \mathrm{~s}$ and the foam heights were taken at different time intervals. The experiment was carried out in duplicate.

The foaming capacity, $\mathrm{F}_{\mathrm{C}}$ was defined by the percentage of volume of foam (Equation 1)

$F_{C}=\frac{\text { Volume after shaking }- \text { Volume before shaking }}{\text { Volume before shaking }} \times 100$

The foam stability, $\mathrm{F}_{\mathrm{S}}$ was calculated for different times, $\mathrm{t}$ $(\mathrm{t}=1,5,15,25,40 \mathrm{~min}$ ) (Equation 2).

$\mathrm{F}_{\mathrm{S}}=\frac{\text { foam volume after time }, \mathrm{t}}{\text { initial foam volume }} \times 100$

\subsection{Detergency}

The detergency properties of the surfactants were determined using the modified procedure reported by Pukale et al. (2016) [23]. Swatches (white cotton fabrics of size $4 \mathrm{~cm} \times 4 \mathrm{~cm}$ ) were stained separately with mud, dry soil, vegetable oil and suspensions/solutions of Indian spice, red wine and coffee in water for $2 \mathrm{~min}$. The stained swatches were dried for at least $24 \mathrm{~h}$. Solutions $1 / 2 / \mathrm{SDS}(1.00 \mathrm{~g} / \mathrm{L})$ and pure distilled water were separately added in the ratio $1: 10$ in $250 \mathrm{~mL}$ washing pots. The stained swatches were placed in the resulting solutions and were washed for $20 \mathrm{~min}$ at an agitation speed of $50 \mathrm{rpm}$ in the lab dyeing machine at $25^{\circ} \mathrm{C}$ and $40^{\circ} \mathrm{C}$. The swatches were then rinsed twice with $100 \mathrm{ml}$ of distilled water for $5 \mathrm{~min}$ and dried prior to detergency determination. The reflectance at $440 \mathrm{~nm}$ of the swatches before and after staining was recorded.

The experiment was carried out in duplicate. The efficiency of the detergent was calculated using Equation 3.

\% Detergency $=\frac{R_{1}-R_{2}}{R_{3}-R_{2}} \times 100$

Where $\mathrm{R}_{1}=$ average reflectance of the swatches after washing, $R_{2}=$ average reflectance of the prewash swatch, $\mathrm{R}_{3}=$ average reflectance of the unstained swatch

The detergency was also expressed as: $\Delta R=R_{1}-R_{2}$

\subsection{Antibacterial activity}

Antibacterial tests were carried out against gram positive bacterial strains, namely Staphylococcus aureus (ATCC 29213) and Bacillus cereus (ATCC 11778) and the gram negative bacteria Klebsiella pneumonia (ATCC 13883) and Pseudomonas aeruginosa. Sodium dodecyl sulfate (SDS) was used as positive control. The antibacterial activities of the compounds were determined by the micro-dilution assay in a 96-well ELISA plate.

\subsection{Molecular Docking}

The structures of sodium cocoate $\mathbf{1}$, sodium cocyl prolinate $\mathbf{2}$ and SDS were drawn and optimised using Avogadro 1.2.0 software and used as input for the docking calculations. The crystal structure of spike protein of SAR-CoV (PDB id: $3 \mathrm{SCI})$ and savinase enzyme (PDB, id: $1 \mathrm{SVN}$ ) were obtained from the Protein Data Bank. Gasteiger-Marsili charges [24] assigned to the ligands using Open babel 2.3.90 [25] and imported, together with the enzyme, into AutoDockTools. Docking was subsequently carried out using the Autodock 4.2 software [26]. A Lamarckian Genetic Algorithm (GA) was used to generate 100 low energy conformations in which the flexible ligands were docked in the vicinity of Phe 442, Phe 472, Asn 479, Asp 480 and Thr 487 residues for the spike protein of SARS-CoV and His 64, Asp 32 and Ser 221 residues for the savinase enzyme. For the spike protein of SARS-CoV, docking was done inside a three-dimensional grid box of size $(70 \times 70 \times 70) \AA$, with a grid spacing of $0.375 \AA$, centered on the Phe 442, Phe 472, Asn 479, Asp 480 and Thr 487 residues, while for the savinase enzyme, docking on a three-dimensional grid box of size $(60 \times$ $60 \times 60) \AA$, with a grid spacing of $0.375 \AA$, centered on the His 64, Asp 32 and Ser 221 residues was carried out. Various different binding poses were found and in order to generate comparable binding pockets for each surfactant, a large number of conformations had to be generated. In the interest of brevity, we only discuss in detail the docked conformations with the lowest free energy of binding, in each case. Interaction diagrams were made with igPlot $^{+}$[27].

\section{Results and Discussion}

\subsection{Synthesis of sodium cocoate surfactant 1 and sodium cocyl prolinate 2}

The coconut oil is a mixture of triglycerides consisting mainly of 10 fatty acids from medium and short chain, from which $91.6 \%$ were saturated, $6.4 \%$ monounsaturated and $1.8 \%$ polyunsaturated fatty acids. These data were consistent with what was reported in the literature [28]. However, 
apart from the fatty acids in the coconut oil reported by Sreenu et al., (2015) [19], the coconut oil from Agalega was also found to contain hexanoic acid and eicosanoic acid with percentage composition of $0.48 \%$ and $0.07 \%$ respectively. Dodecanoic acid was found to be the most abundant fatty acid in the coconut oil with a percentage composition of $46.60 \%$. Sodium cocoate surfactant 1 was synthesized by the saponification reaction of the virgin coconut oil with $\mathrm{NaOH}$ to form sodium salts of fatty acid mixtures. The sodium cocyl prolinate surfactant 2 was synthesised in 2 steps (Fig. 1). The coconut oil was first hydrolysed with aqueous $\mathrm{NaOH}$. The fatty acid mixture obtained was then converted to their fatty acid chloride derivatives which were then reacted with proline in THF in the presence of TEA/ DMAP, followed by stirring with $\mathrm{NaOH}$ in methanol to yield the desired surfactant 2 . Since dodecanoic acid is the most abundant fatty acid in the coconut oil, the molecular weight of the surfactant 1 and 2 were taken to be approximately the same as the molecular weight of sodium dodecanoate (MW: 222.3) and sodium dodecanoyl prolinate (MW: 319.41) respectively and used for further calculation.

The formation of the amide linkage was confirmed by the sharp peak at $1616 \mathrm{~cm}^{-1}$ in the IR spectrum of 2 . The peaks at 1559 and $1444 \mathrm{~cm}^{-1}$ were assigned to the carboxylate anion of the sodium salt.

The structure of the desired surfactant 2 was further confirmed by ${ }^{\mathrm{I}} \mathrm{H} N \mathrm{NMR}$ and ${ }^{13} \mathrm{C}$ NMR spectra. The peak for methylene protons adjacent to the amide group appeared at $\delta 3.31-3.41 \mathrm{ppm}$ as a multiplet while the methylene protons of the proline moiety appeared as multiplets at $\delta 1.74-$ $1.82 \mathrm{ppm}$ and $1.99-2.09 \mathrm{ppm}$. The peak at $\delta 61.6 \mathrm{ppm}$ in the ${ }^{13} \mathrm{C}$ NMR of surfactant 2 corresponded to the methine carbon of the proline moiety. The peaks at $\delta 22.6-34.5 \mathrm{ppm}$ corresponded to the methylene carbons of the fatty acid alkyl chains and proline moiety while the peak at $\delta 13.9 \mathrm{ppm}$ was assigned to the terminal methyl carbon.

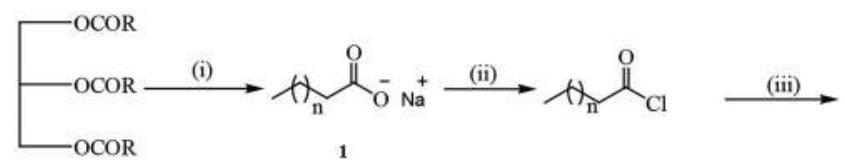

$\mathrm{n}=4,6,8,10,12,14$

\subsection{Physicochemical Properties}

\subsubsection{Critical Micelle Concentration (CMC)}

The CMCs of the synthesized surfactants 1 and 2 were determined by using the conductivity method. The CMC value of each surfactant was taken at the point where an abrupt change in the conductivity was observed in each graph (Fig. 2).

The CMC values of surfactants 1 and 2 were $15.25 \mathrm{mM}$ and $3.81 \mathrm{mM}$ respectively. Due to the presence of mixtures of fatty acids sodium salts with different chain length in surfactant 1, mixed micelles were formed which led to lower $\mathrm{CMC}$ values compared to the $\mathrm{CMC}$ value reported for pure sodium dodecanoate [29]. Sodium cocyl prolinate 2 was found to possess a lower CMC value compared to sodium cocoate 1 , which was probably due to the hydrophobic contribution of additional cyclic proline moiety, hence favouring micellar formation. The CMC value obtained for sodium cocyl prolinate 2 was slightly higher to that reported by Sreenu et al. [19].

\subsubsection{Krafft temperature}

Krafft point is the minimum temperature at which a surfactant forms micelles in aqueous solution. The Krafft temperature of the synthesized surfactants 1 and 2 was determined using conductivity method and compared to that of the commercially available surfactant sodium dodecyl sulfate (SDS). The Krafft temperature of the surfactant was taken at the point where a prominent change was observed in the gradient of the plot of conductivity versus temperature (Fig. 3). The Krafft temperature of $\operatorname{SDS}\left(16.5^{\circ} \mathrm{C}\right)$ was in line with the reported value [30]. The surfactants 1 and 2 were found to possess lower a Krafft temperature $\left(9.5^{\circ} \mathrm{C}\right.$ and $1^{\circ} \mathrm{C}$ respectively) compared to SDS. The lower value may be attributed to the presence of longer fatty acid chains, which have the tendency to micellise much easier as compared to $\operatorname{SDS}\left(\mathrm{C}_{12}\right)$.
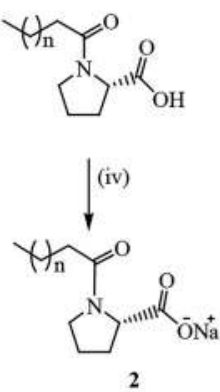

(i) Aqueous $\mathrm{NaOH}, 90^{\circ} \mathrm{C}, 4 \mathrm{~h}$ (ii) dil $\mathrm{HCl}, \mathrm{SOCl}_{2}, \mathrm{DCM}, 3 \mathrm{~h}$ (iii) L-proline, TEA, DMAP, $18 \mathrm{~h}$, (iv) Figure 1 Synthesis of coconut oil surMethanolic $\mathrm{NaOH}$, r.t factant 1 and $N$-acyl prolinate surfactant 2

\begin{tabular}{|c|c|c|c|}
\hline \%FS at time, $\mathrm{t}$ min & SDS & Surfactant 1 & Surfactant 2 \\
\hline 1 & $91.4 \pm 0.9$ & $54.5 \pm 0.8$ & $56.9 \pm 0.7$ \\
\hline 5 & $86.2 \pm 0.9$ & $25.0 \pm 1.6$ & $19.3 \pm 0.4$ \\
\hline 15 & $83.3 \pm 0.9$ & $5.11 \pm 1.1$ & $9.4 \pm 0.3$ \\
\hline 25 & $82.4 \pm 0.9$ & $0.6 \pm 0.0$ & $7.4 \pm 0.2$ \\
\hline 40 & $81.0 \pm 0.9$ & $0.0 \pm 0.0$ & \\
\hline
\end{tabular}

Table 1 Foaming stability of surfactant 1,2 and SDS 


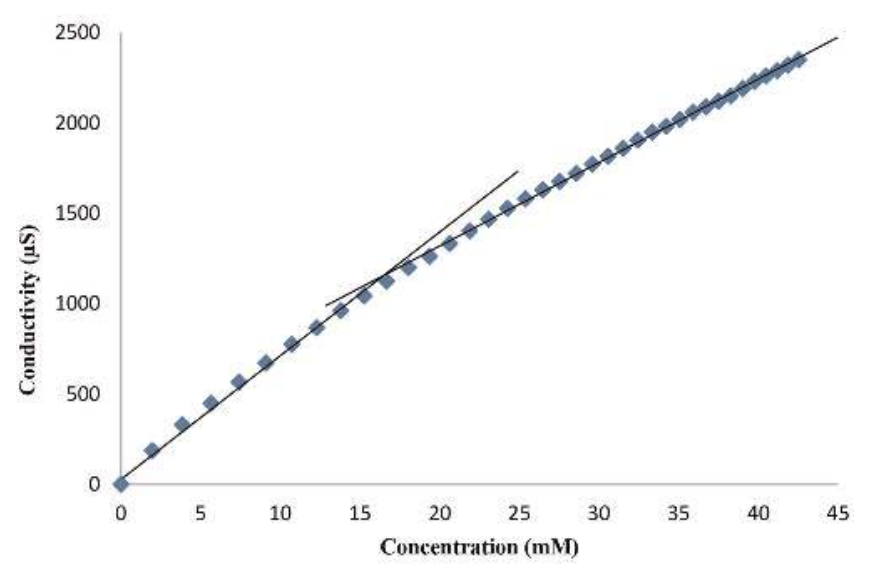

(a)

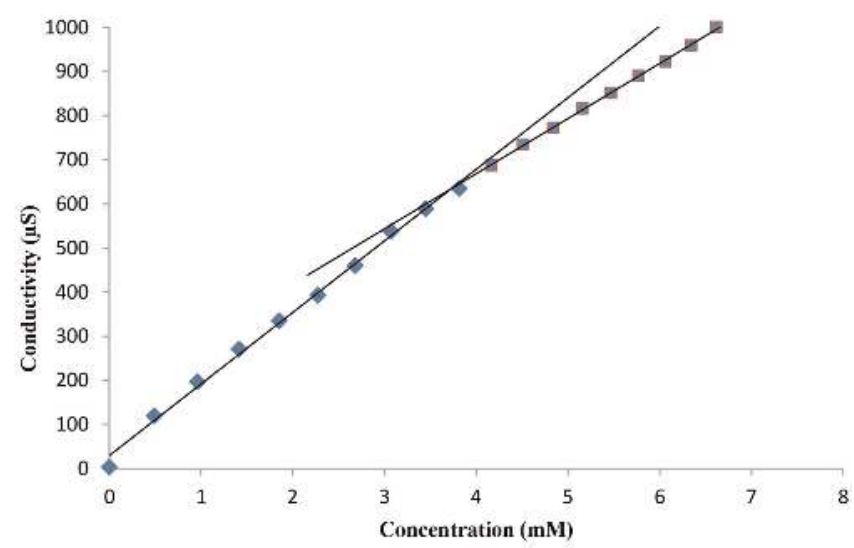

(b)

Figure 2 Graph of conductivity against concentration of (a) sodium cocoate 1 and (b) sodium cocyl prolinate 2

\subsubsection{Foaming capacity and foaming stability}

Low and high foaming ability of surfactants are considered as useful in the industrial field depending on their applications. Low foaming surfactants are used as additional ingredient in hospital laundry or automatic dishwashing formulations while high foaming surfactants are used for shampoos and hand washing detergents [31]. In view of studying their applications as potential ingredients in detergent formulations, the foaming ability of sodium cocoate surfactant 1 and sodium cocyl prolinate surfactant 2 were evaluated and compared to that of the conventional surfactant SDS (Table 1).

Over the period of $1 \mathrm{~h}$ it was observed that surfactants 1 and 2 showed a relatively lower foaming ability and stability as compared to SDS (Fig. 4). Sodium cocyl prolinate surfactant 2 showed better foaming ability as compared to sodium cocoate surfactant 1 , which may be due to the presence of the cyclic proline moiety (Fig. 4). The lower foaming ability of surfactants 1 and 2 makes them ideal candidates to be used in washing machine laundry detergent formulation rather than in hand washing detergent formulation.

\subsection{Detergency}

The detergency of surfactants 1 and 2 were evaluated in terms of their ability to remove different types of stains, namely red wine, mud, coffee, vegetable oil, Indian spice and dry soil from cotton fabric. It was reported that detergent activity of surfactants is influenced by temperature

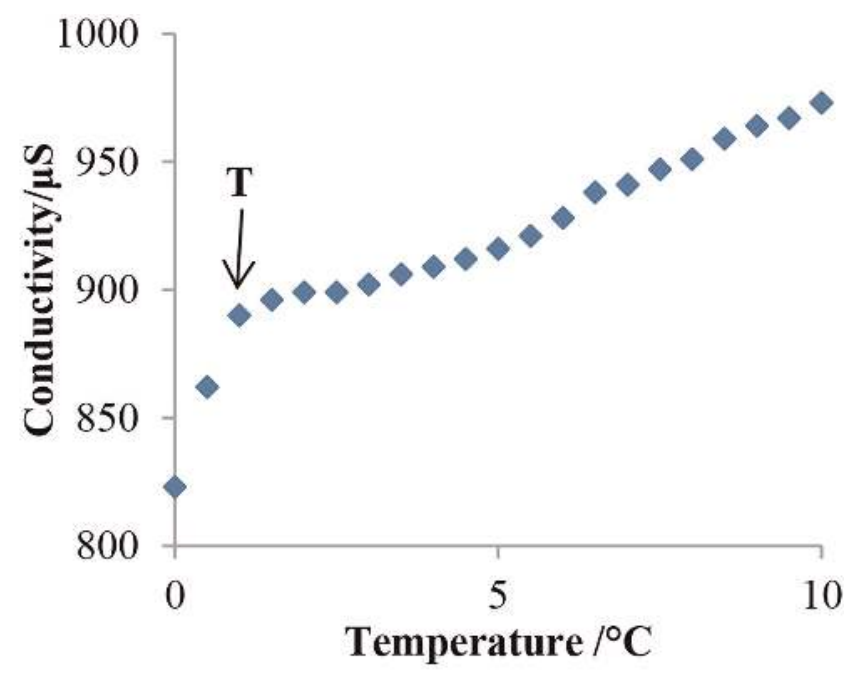

(a)

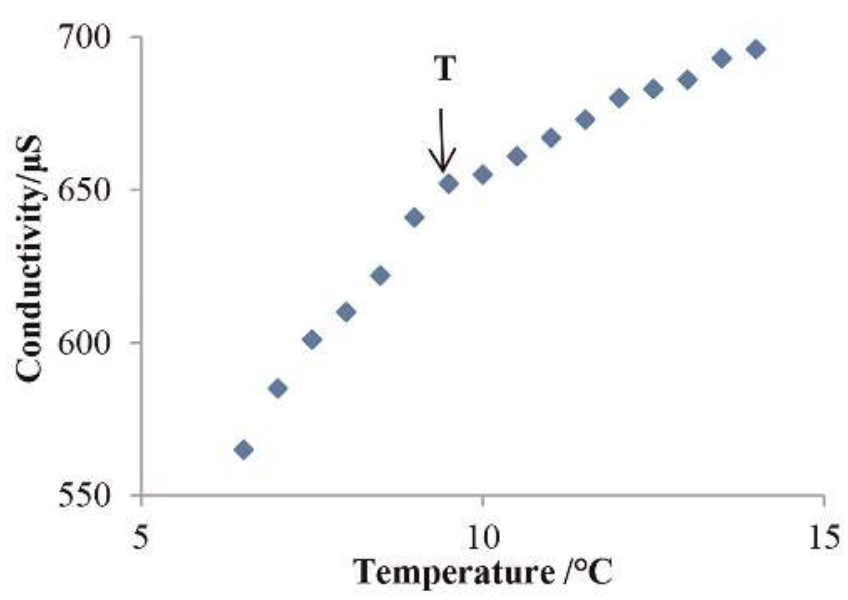

(b)

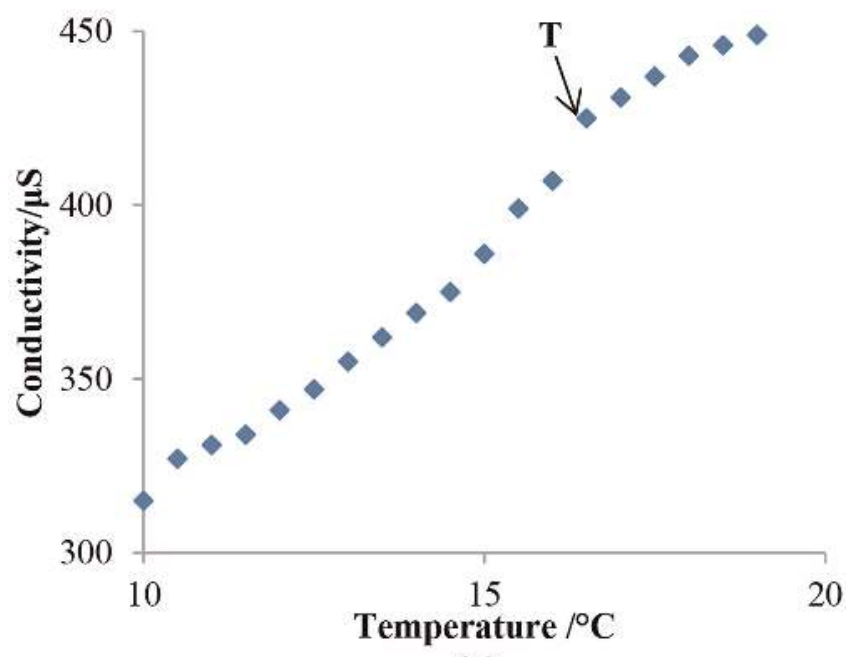

(c)

Figure 3 Variation of conductivity of solutions of (a) Sodium cocoate 1 (b) Sodium cocyl prolinate 2 and (c) SDS against temperature 


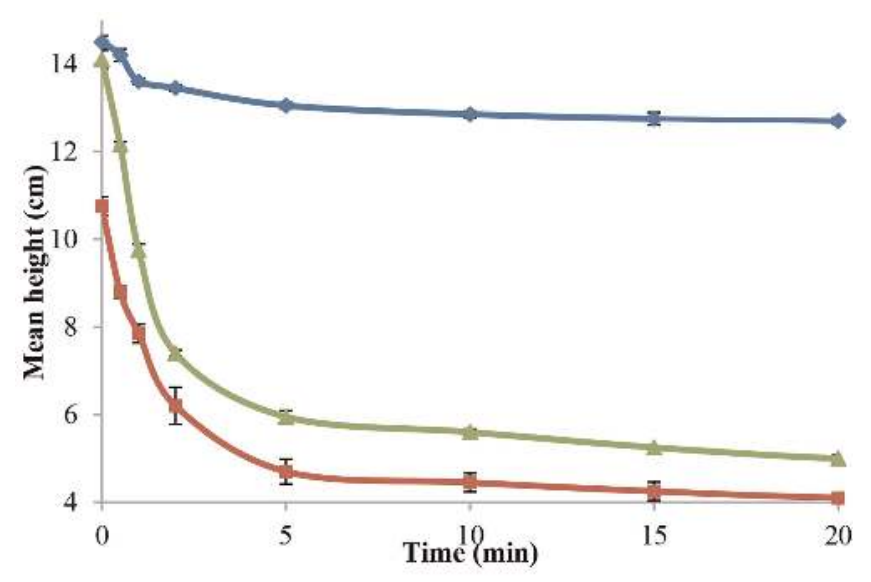

- Surfactant $1-$ Surfactant $2 \multimap$ SDS

Figure 4 Mean foam height of surfactant 1, 2 and SDS as a function of time

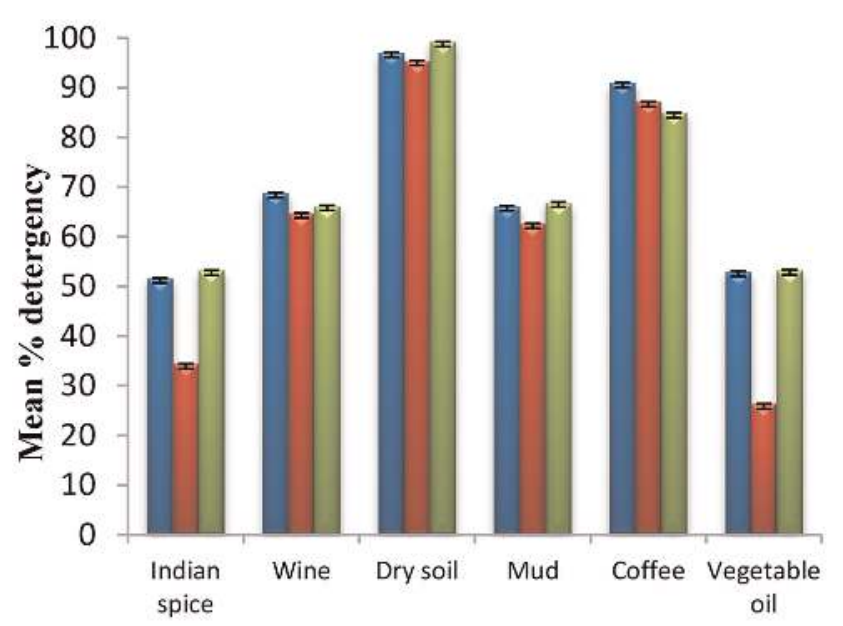

(a)
[32]. Therefore, the experiments were carried out at $25^{\circ} \mathrm{C}$ and $40^{\circ} \mathrm{C}$. The reflectance of the swatches with the different stains are illustrated in the Fig. 6 and 7.

Surfactant 2 was found to have a more effective washing performance at $25^{\circ} \mathrm{C}$ than surfactant 1 and SDS, which was reflected in the higher $\Delta \mathrm{R}$. This might be due to the lower Krafft temperature of surfactant 2, which enables the surfactant to form micelles at much lower temperature, hence making it act as an effective detergent at room temperature. This showed that surfactant 2 exerts its detergency action much better than surfactant 1 and SDS as well as being more energy-efficient. In most cases, an increase of temperature from $25^{\circ} \mathrm{C}$ to $40^{\circ} \mathrm{C}$ showed an increase of $\Delta \mathrm{R}$ (difference between pre washed and washed fabric) which indicated an increase of detergent activity (Table 2 and Fig. 5).

It was found that the detergency of the surfactants 1, 2 and SDS varies depending on the type of stains. The surfactants 1, 2 and SDS were found to be effective in removing soil particles from fabrics in which surfactant 2 and SDS have a comparable detergent activity. Surfactant 2 was proved to be more effective against red wine, mud, coffee

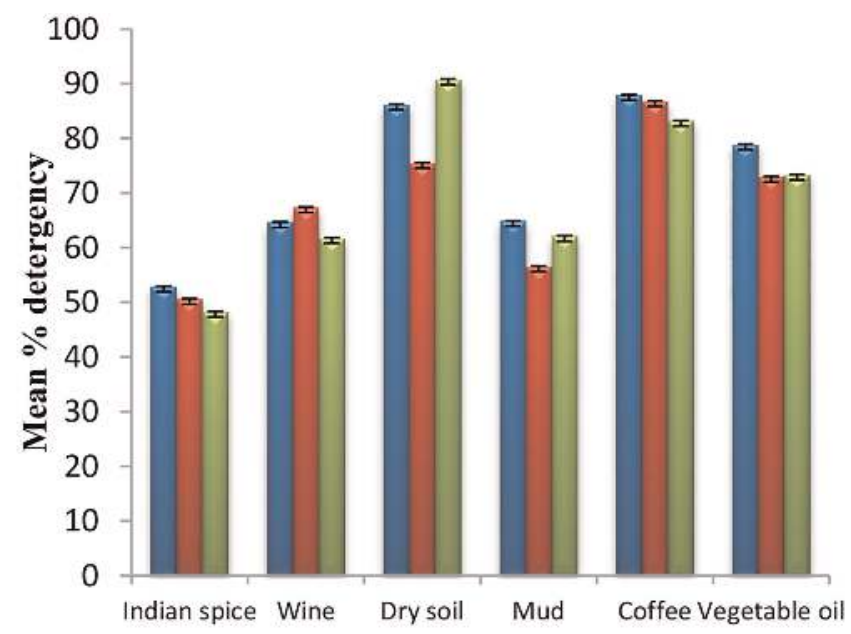

(b)

Surfactant 1

Surfactant 2

SDS

Figure $5 \%$ Detergency of surfactants 1, 2 and SDS at (a) $25^{\circ} \mathrm{C}$ and at (b) $40^{\circ} \mathrm{C}$

\begin{tabular}{|c|c|c|c|c|c|c|}
\hline \multirow{3}{*}{ Stains } & \multicolumn{6}{|c|}{$\Delta \mathrm{R}$} \\
\hline & \multicolumn{2}{|c|}{ Surfactant 1} & \multicolumn{2}{|c|}{ Surfactant 2} & \multicolumn{2}{|c|}{ SDS } \\
\hline & $25^{\circ} \mathrm{C}$ & $40^{\circ} \mathrm{C}$ & $25^{\circ} \mathrm{C}$ & $40^{\circ} \mathrm{C}$ & $25^{\circ} \mathrm{C}$ & $40^{\circ} \mathrm{C}$ \\
\hline Red wine & 41 & 53 & 45 & 50 & 42 & 45 \\
\hline Mud & 42 & 46 & 55 & 49 & 50 & 50 \\
\hline Coffee & 81 & 84 & 85 & 86 & 79 & 81 \\
\hline Vegetable oil & 2 & 15 & 5 & 17 & 5 & 16 \\
\hline Indian spice & 29 & 48 & 44 & 49 & 44 & 45 \\
\hline Dry soil & 24 & 33 & 24 & 46 & 19 & 42 \\
\hline
\end{tabular}

Table 2 Detergency of surfactant 1 and 2 and SDS 

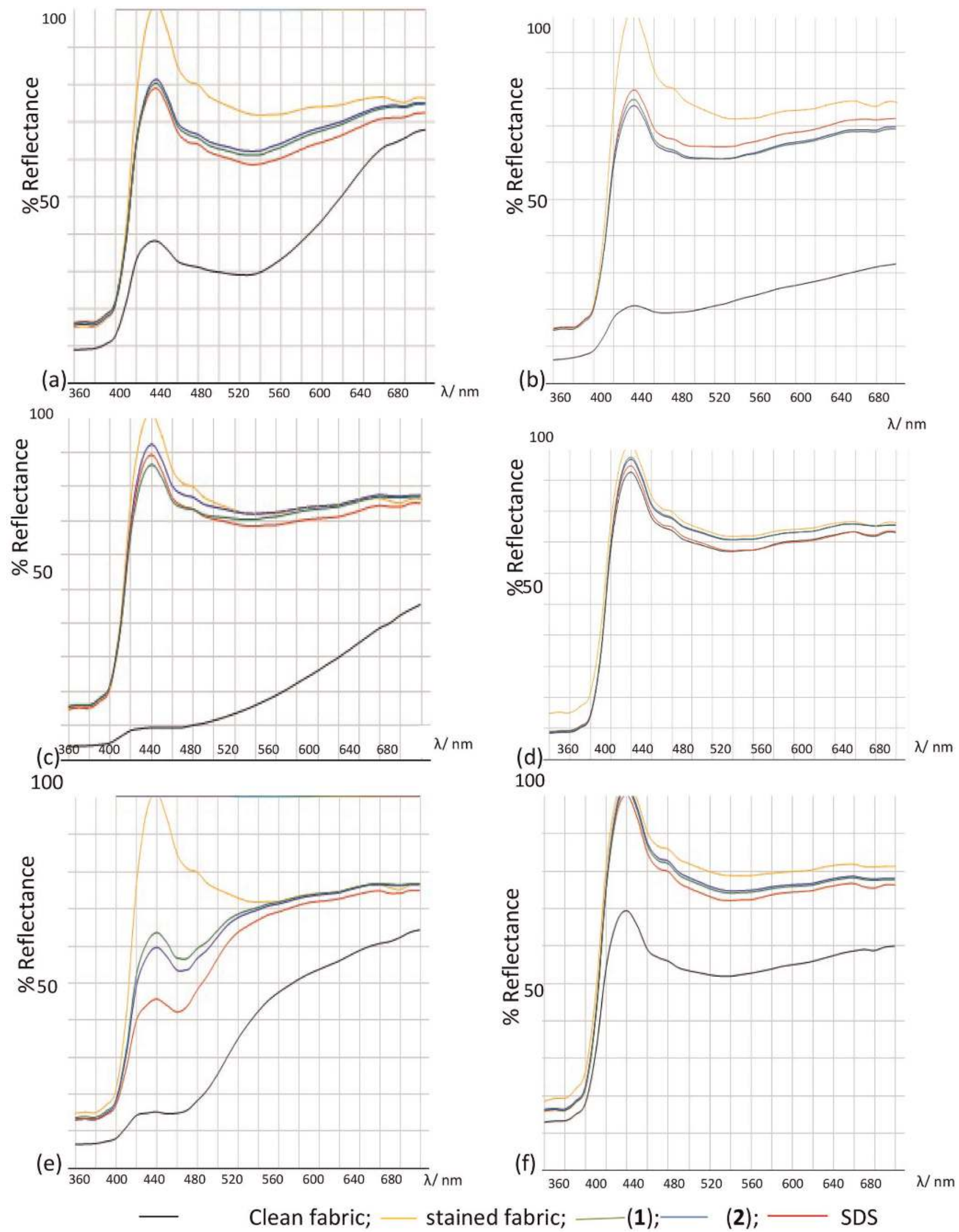

Figure 6 Detergency activities on (a) red wine (b) mud (c) coffee (d) vegetable oil (e) Indian spice (f) dry soil at room temperature 

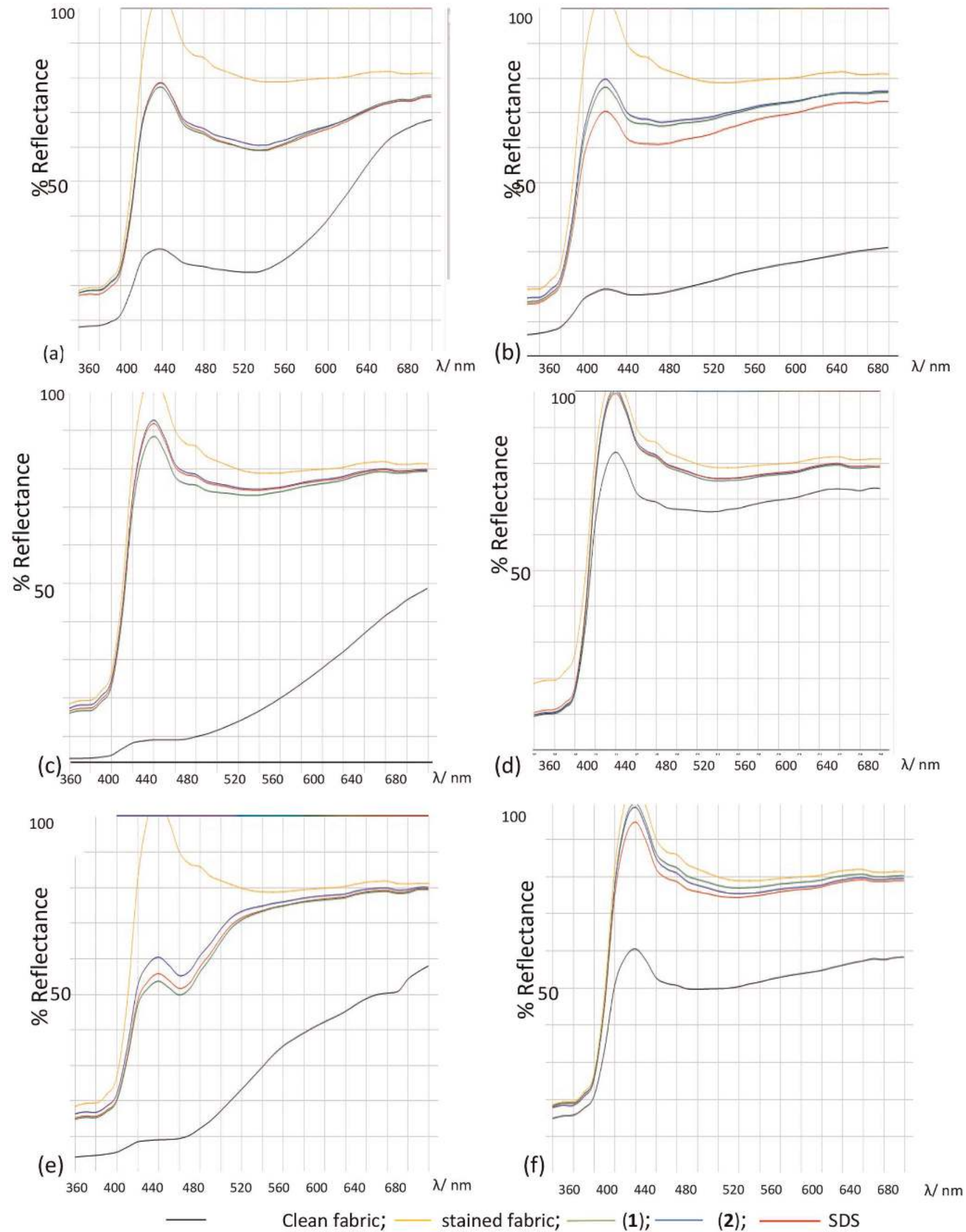

Figure 7 Detergency activities on (a) red wine (b) mud (c) coffee (d) vegetable oil (e) Indian spice (f) dry soil at $40^{\circ} \mathrm{C}$ 
stains and vegetable oil compared to surfactant 1 and SDS. In the literature vegetable oil has been classified as one of the most persistent oily stains to be removed from cloth [33]. The surfactants proved to act more efficiently on swatches stained with vegetable oil at high temperature $\left(40^{\circ} \mathrm{C}\right)$. It was also observed that the surfactants acted to the same extent on Indian spices at both room temperature and $40^{\circ} \mathrm{C}$.

\subsection{Antibacterial activity}

One of the most important properties of laundry detergent is their ability to exert antimicrobial action against a range of pathogens. Bacteria such as Staphylococcus aureus form part of the normal skin flora and can be responsible for numerous skin infections. Bacillus cereus is another bacterial strain that is commonly present in soil and food. Hence, laundry detergents should not only exert their cleaning action, but should also be able to kill and inactivate these types of bacterial strains in contaminated fabrics. In this view, the antibacterial properties of surfactants 1 and 2 were evaluated against gram-positive and gram-negative strains (Table 3).

Surfactants 1 and 2 showed moderate antibacterial activities against gram-positive bacteria. Surfactants 1 and 2 displayed lower MIC values compared to SDS, which indicated their better antibacterial activity over the conventional surfactant commonly used in laundry detergents. However, surfactants 1 and 2 as well as SDS showed minimal activity against the gram-negative bacteria $K$. pneumoniae and $P$. aeruginosa at the concentrations tested.

\subsection{Molecular docking with spike protein of SARS-CoV-2}

As the new coronavirus continues to spread, people are taking increasingly stringent precautions to ensure that their home environments are free from the virus and decreasing the risk of infection. Although the new coronavirus is typically transmitted through respiratory droplets, the virus may remain viable for hours to days on surfaces made from a variety of materials, including clothing, and can be transmitted on contact if these materials are contaminated.
In the fight against coronavirus, the spike protein, which mediates the virus entry into host cells, remains one of the main targets to render the virus ineffective; hence, the interactions between various potential drugs and spike protein have been reported [34]. In view of studying the ability of surfactants 1 and 2 to act as promising detergent ingredients against the spread of coronavirus infections, molecular docking experiments of the surfactants 1 and 2 with the spike protein of SARS-CoV was carried out and the results were compared with that of SDS.

It has been reported that specific amino acids at the 442 , $472,479,480$, and 487 positions of the spike protein enhances the binding of the virus to the host receptors [35]. Therefore, in order to study the effectiveness of the surfactants against SARS-CoV, surfactants 1 and 2 were docked at the vicinity of Phe 442, Phe 472, Asn 479, Asp 480 and Thr 487. The results are given in Table 4.

All three surfactants showed negative binding free energies in the vicity of all five amino acids, indicating that the binding between the surfactants and spike protein of SARS$\mathrm{CoV}$ is favourable. Surfactant 2 displayed promising interactions with the spike protein, showing mostly the highest affinity to the key amino acids. Analysis of the binding pocket of the spike protein amino acid residues showed that surfactant 2 interacts with the amino acid residues Phe 442, Phe 472, Asn 479 and Asp 480 mostly via hydrophobic interactions (Fig. 8). Although surfactant 2 was able to bind in the vicinity of Thr 487, there were no direct interaction between the surfactant and Thr 487. In addition to the hydrophobic interactions, Surfactant 2 was also found to form hydrogen bonds with Asn 457, Lys 439, Lys 465, Lys 31 and Gln 76.

\subsection{Molecular docking with savinase enzyme}

Enzymes and surfactants are both essential ingredients that determine the performance of modern laundry detergents. The purpose of detergent enzymes is to cleave complex biological molecules, which, will eventually be removed. Many anionic surfactants are known to denature the enzymes present in the detergents, rendering them ineffective in performing their actions [36]. To find a better performing deter-

\begin{tabular}{|c|c|c|c|c|}
\hline \multicolumn{2}{|c|}{ Microorganisms } & \multicolumn{3}{c|}{ MIC $(\mu \mathrm{M})$} \\
\cline { 3 - 5 } & & 1 & 3 & 391 \\
\hline Gram positive & S. aureus & 781 & 48.8 & 586 \\
\hline Gram negative & B. cereus & 36.6 & - & 391 \\
\hline & K. pneumoniae & - & - & - \\
\hline
\end{tabular}

Table 3 Antibacterial activity of surfactants 1 and 2

\begin{tabular}{|c|c|c|c|c|c|}
\hline & \multicolumn{4}{|c|}{ Binding free energy (kJ/mol) } \\
\hline & Phe 442 & Phe 472 & Asn 479 & Asp 480 & -19.58 \\
\hline Surfactant 1 & -19.37 & -16.36 & -17.36 & -19.29 \\
\hline Surfactant 2 & -20.38 & -16.86 & -24.14 & -21.25 \\
\hline SDS & -20.21 & -14.35 & -22.38 & -21.55 & -20.96 \\
\hline
\end{tabular}

Table 4 Binding free energies of surfactants 1,2 and SDS with spike protein of SARS-CoV 


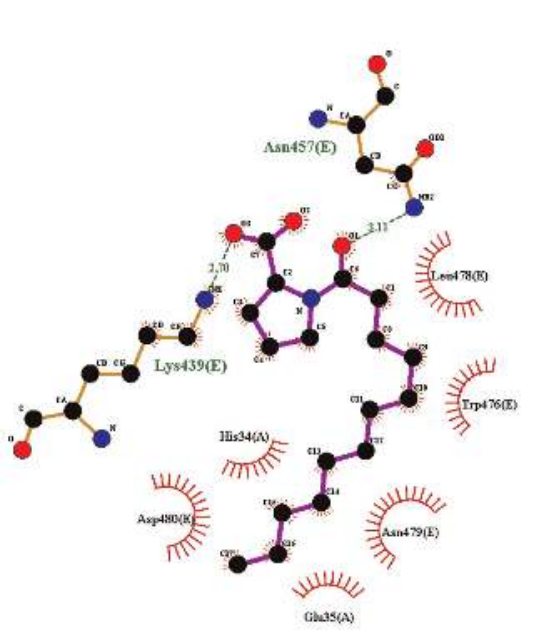

(a)

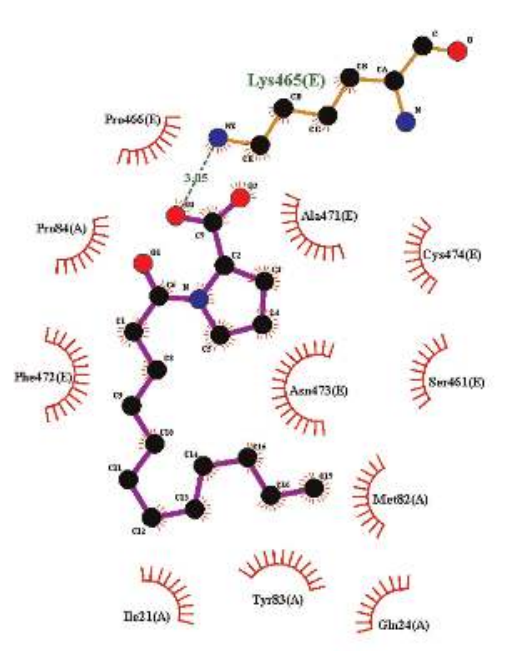

(b)

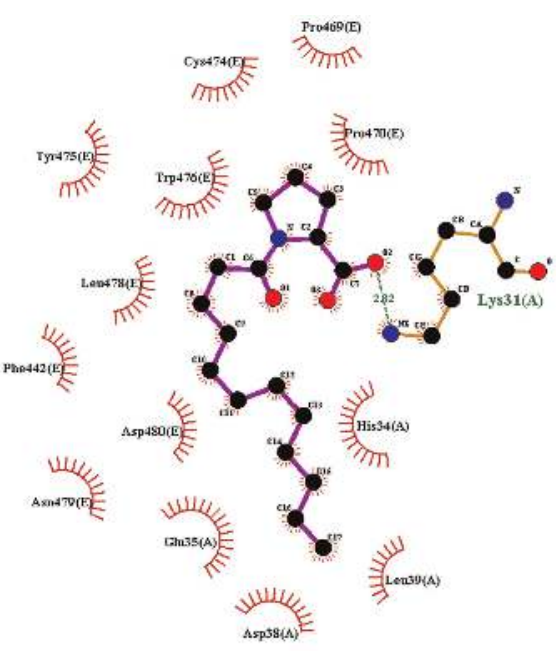

(c)

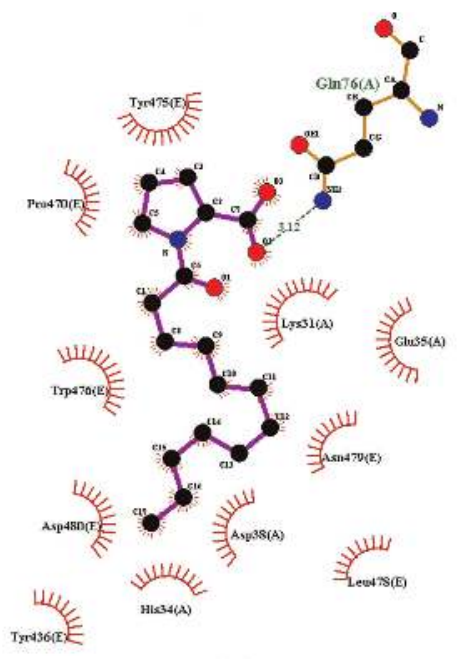

(d)

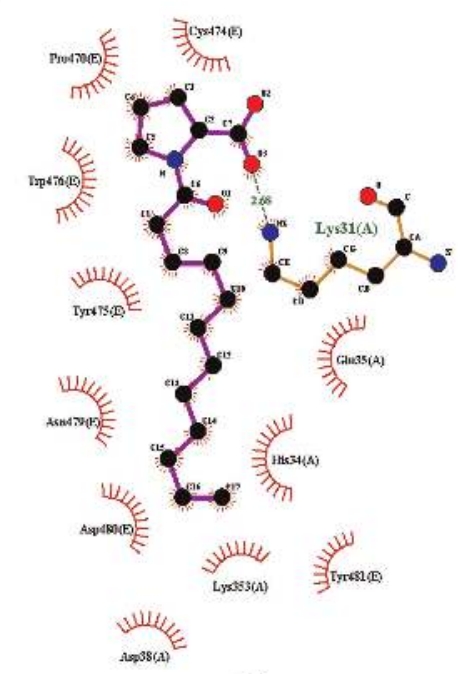

(e)

Figure 8 Interaction diagrams for docking of surfactant 2 in the vicinity of (a) Phe 442, (b) Phe 472, (c) Asn 479, (d) Asp 480 and (e) Thr 487 residues

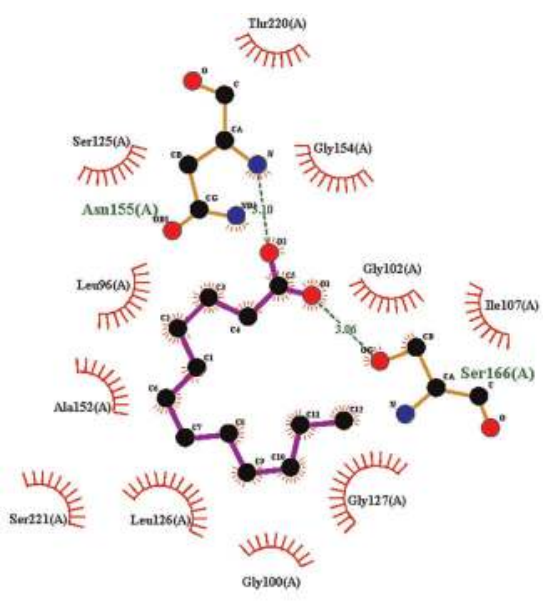

(a)

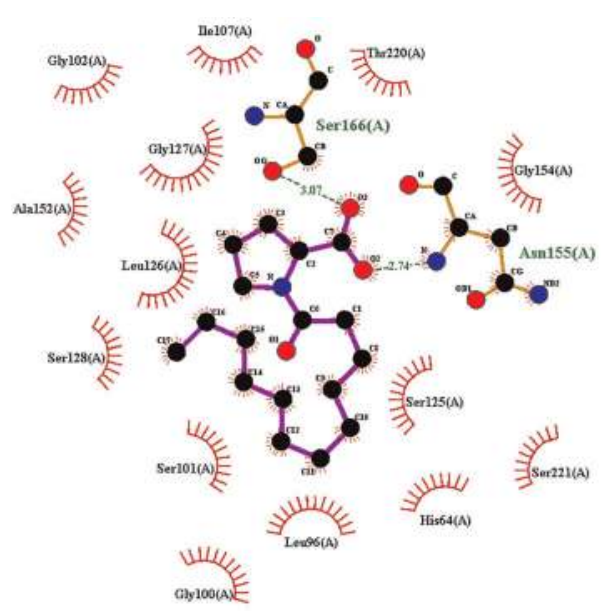

(b)

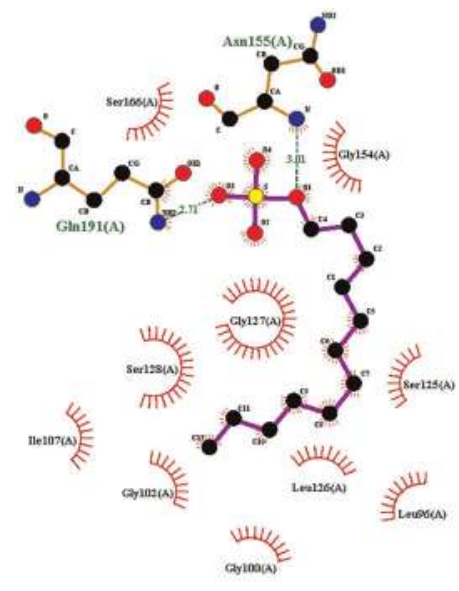

(c)

Figure 9 Interaction diagrams for docking of compounds in the vicinity of His 64 residue 


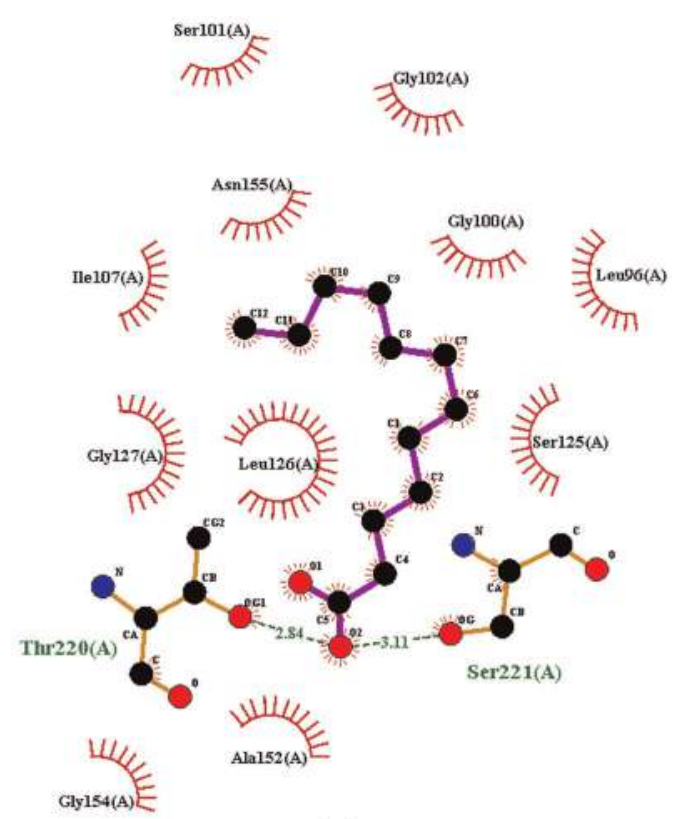

(a)

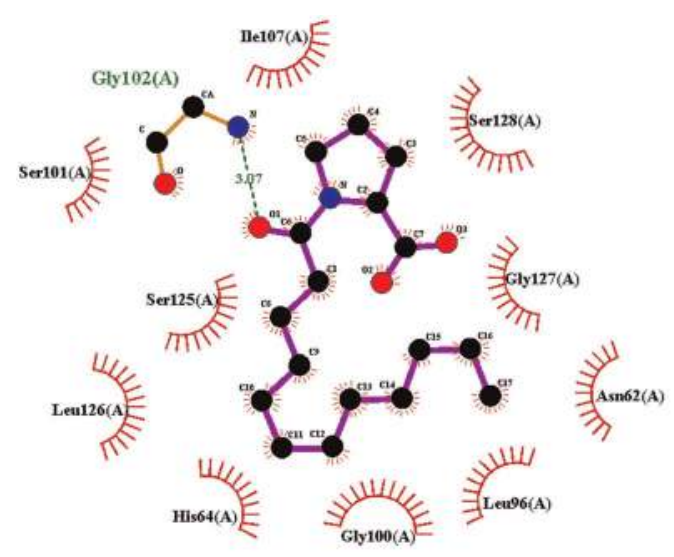

$$
\underset{\text { Thr33(A) }}{4}
$$

(b)

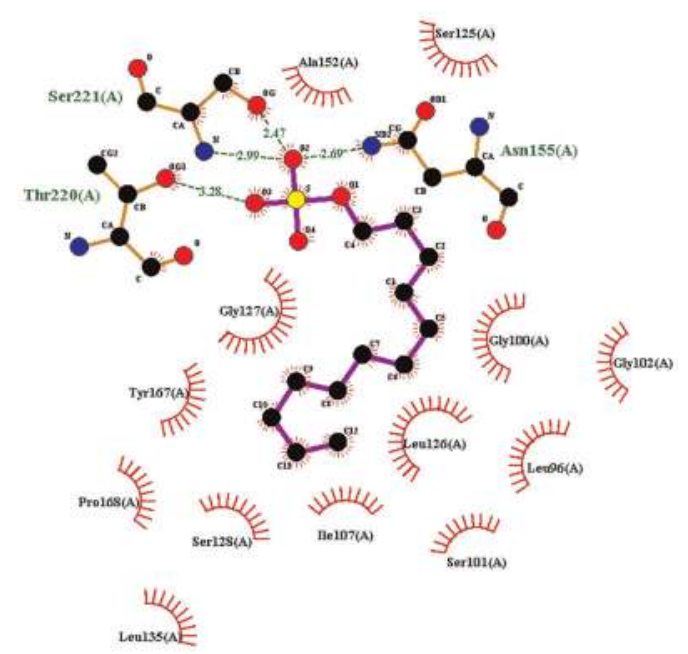

(c)

Figure 10 Interaction diagrams for docking of compounds in the vicinity of Asp 32 residue

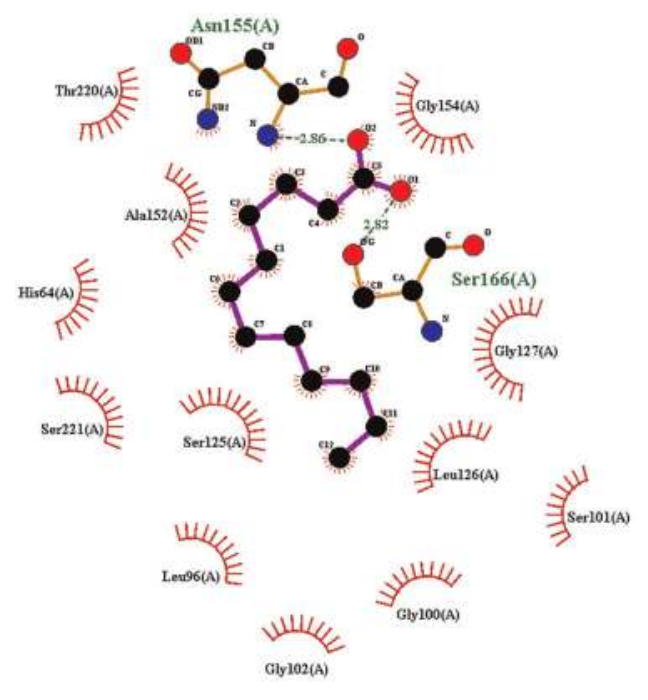

(a)

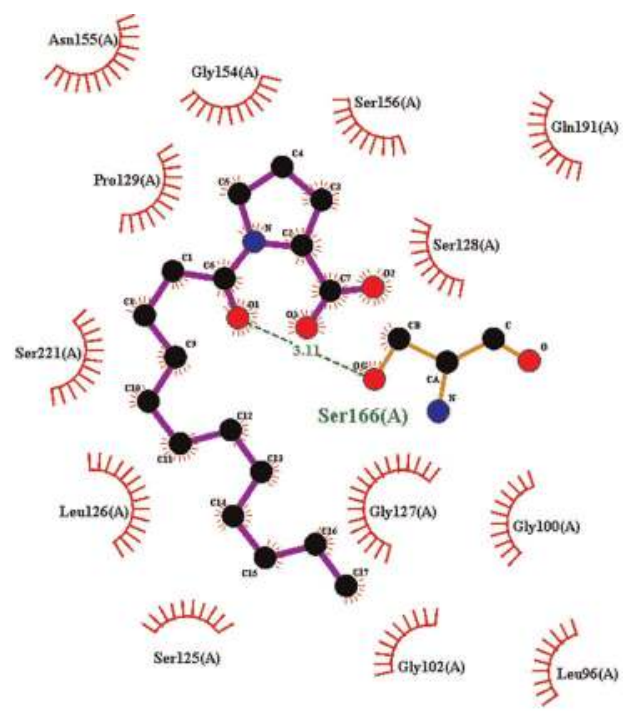

(b)

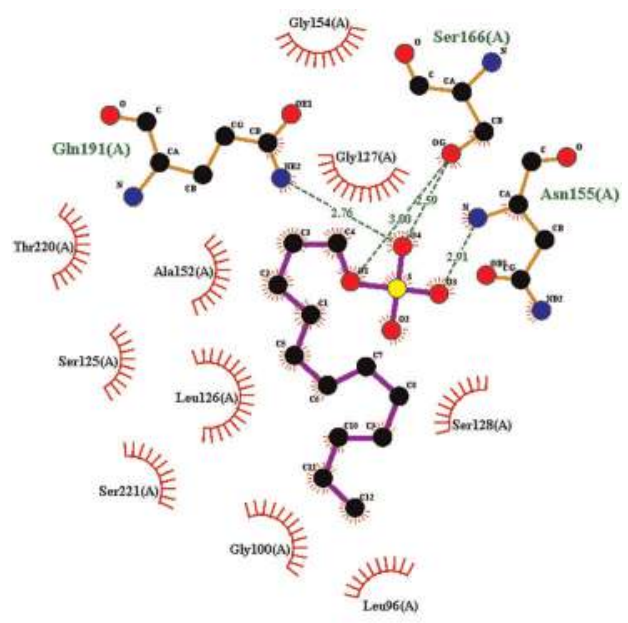

(c)

Figure 11 Interaction diagrams for docking of compounds in the vicinity of Ser 221 residue 
gent formulation, both the enzyme and the surfactant system have to be adapted to coexist and to work together in the best possible way. Therefore, a suitable surfactant for laundry detergent should be designed in such a way that unfolding of the enzyme structure is avoided, which leads to the enzyme losing its three-dimensional structure and being denaturared.

Savinase, a serine proteinase has gained considerable interest as protein-degrading additives to detergents in the washing-powder industry $[37,38]$ and is used in detergent formulations to remove protein based stains. Savinase consists of 269 amino acids and the gene sequence is known [39]. The amino acid residues Asp32, His64 and Ser221 were found in the active site of savinase, forming the catalytic triad.

In order to study the interaction of surfactant 1, 2 and SDS with savinase, molecular docking was performed at the amino acid residues Asp32, His64 and Ser221, which lies in the active site of the enzyme forming a catalytic triad.

The binding pocket was analyzed to identify the full list of savinase enzyme residues that interacted with the surfactant 1, 2 and SDS. All the three surfactants were found to interact with Ser 221 by hydrophobic interactions. Surfactant 1 and SDS were also found to interact with Ser 221 by hydrogen bonding. Surfactant 1 and 2 were found to interact with His 64 residue by hydrophobic interaction. None of the three surfactants seem to interact directly with the Asp 32 residue, although they were able to bind in the vicinity of the residue. All three surfactants were found to interact with Asn 155 residue via hydrogen bonding (Fig. 9-11).

Apart from Asn 155, the carboxylate group of surfactant 1 and 2 were found to form a hydrogen bond with the Ser 166 residue, while the sulfonate moiety of SDS was found to interact with Gln 191. Comparing the binding affinities, all three surfactant 1, 2 and SDS showed negative free binding energies $\left(\Delta \mathrm{G}_{\text {bind }}\right)$ with savinase, which indicated favourable interaction with the enzyme (Table 5). In all three amino acid residues in the catalytic triad, the surfactants were able to interact with savinase in the order Surfactant $2>$ SDS $>$ Surfactant 1. However, the difference in their binding energy value was very small, which implies that the interactions of the surfactants 1, 2 and SDS with savinase were comparable. This concluded that the proline based surfac- tant 2 should display a similar behavior to that of the conventional SDS, which is the most widely used surfactant in the laundry industry.

\section{Conclusions}

Sodium cocyl prolinate surfactant 2 was found to possess superior properties compared to sodium cocoate surfactant 1 and SDS since it was found to micellise much easier and at a lower temperature. This property enables surfactant 2 to exert its detergency action against red wine, mud and coffee stains more effectively at a much lower temperature $\left(25^{\circ} \mathrm{C}\right)$ compared to sodium cocoate surfactant $\mathbf{1}$ and SDS. The moderate foaming activity of surfactant 2 enables it to act as an ideal candidate to be used in washing machine laundry detergent formulation. Sodium cocyl prolinate surfactant 2 was also found to display better antibacterial activities than SDS. Molecular docking with spike protein of SARS$\mathrm{CoV}$ has shown that surfactant 2 interacts with amino acid residues of spike protein that is responsible for the binding of the virus to host cells. This implies that surfactant 2 can be used as promising ingredient in laundry detergent for the fight against the spread of SARS-CoV by contaminated clothes. Molecular docking with savinase enzyme showed that the sodium cocyl prolinate surfactant $\mathbf{1}$ and $\mathbf{2}$ displayed little interaction with savinase implying that there is no denaturation of the enzyme in the presence of the surfactants. This showed that sodium cocyl prolinate surfactant 2 can be used as a more effective active ingredient in laundry detergent for stain removal, is more energy efficient, has an antimicrobial effect to reduce the spread of infectious diseases.

\section{Acknowledgements}

The authors would like to thank Dr Gerhard A. Venter, Senior Lecturer from the Scientific Computing Research Unit, Department of Chemistry, University of Cape Town, Rondebosch 7701, South Africa, for his valuable and critical suggestions. One of the authors is thankful to the Tertiary Education Commission (TEC), Mauritius for the grant of the scholarship.

\begin{tabular}{|c|c|c|c|}
\hline Surfactant & \multicolumn{2}{|c|}{$\Delta \mathrm{G}_{\text {bind }}\left(\mathrm{kJ} \mathrm{mol}^{-1}\right)$} & Ser 221 \\
\hline & His 64 & Asp 32 & -17.74 \\
\hline 1 & -16.28 & -14.18 & -20.54 \\
\hline SDS & -22.22 & -19.08 & -19.20 \\
\hline
\end{tabular}

Table 5 Binding free energies $\left(\Delta \mathrm{G}_{\text {bind }}\right.$ ) of the surfactants 1,2 and SDS in the vicinity of His 64 , Asp 32 and Ser 221 in Savinase binding sites, as obtained from the molecular docking experiments 


\section{References}

1. Kuntom, A. and Kifli, H.: Properties of soaps derived from distilled palm stearin and palm kernel fatty acids, J Surfactants Deterg. 1 (1998) 329-334. DOI:10.1007/s11743-998-0032-4

2. Scheibel, J. J.: The evolution of anionic surfactant technology to meet the requirements of the laundry detergent industry, J Surfactants Deterg. 7 (2004) 319-328. DOI: 10.1007/s11743-004-0317-7

3. Yu, Y., Zhao, J. and Andrew, E. B.: Development of surfactants and builders in detergent formulation, Chin J Chem Eng. 16 (2008) 517-527. DOI:10.1016/S 1004-9541(08)60115-9

4. Raney, K. H. Benton, W. J. and Miller, C. A.: Optimum detergency conditions with nonionic surfactants: I. Ternary water-surfactant-hydrocarbon systems, J Colloid Interface Sci. 117 (1987) 282-290. DOI:10.1016/0021-9797(87)90192-5

5. Miller, C. A. and Raney, K. H.: Solubilization-emulsification mechanisms of detergency, Colloid Surf A Physicochem Eng Asp. 74 (1993) 169-215. DOI: 10.1016/0927-7757(93)80263-E

6. Duarte, I. C. S., Oliveira, L. L., Maayor, M. S., Okada, D. Y. and Varesche, M. B. A.: Degradation of detergent (linear alkylbenzene sulfonate) in an anaerobic stirred sequencing-batch reactor containing granular biomass, Int Bioderobic stirred sequencing-batch reactor containing granular biomass, Int $\mathrm{B}$
terior Biodegr. 64 (2010) 129-134. DOI:10.1016/j.ibiod.2009.12.003

7. Ramcharan, T. and Bissessur, A.: Analysis of linear alkylbenzene sulfonate in laundry wastewater by HPLC-UV and UV-VIS spectrophotometry, J Surfactants Deterg. 19 (2016) 209-218. DOI:10.1007/s11743-015-1763-x

8. Villar, M., Callejon, M., Jimenez, J. C., Alonso, E. and Guiraum, A.: New rapid methods for determination of total LAS in sewage sludge by high performance liquid chromatography (HPLC) and capillary electrophoresis, Anal Chim Acta. 634 (2009) 267-271. PMid:19185131; DOl:10.1016/j.aca.2008.12.037

9. Vemula, P. K. and John, G.: Crops: A green approach toward self-assembled soft material, Acc Chem Res. 41 (2008) 769-782. PMid:18507403 DOI: 10.1021 /ar7002682

10. Chandra, N. and Tyagi, V. K.: Synthesis, properties, and applications of amino acid-based surfactants: A review, J Disper Sci Technol. 34 (2013) 800-808. DOI:10.1080/01932691.2012.695967

11. Bordes, R. and Holmberg, K.: Amino acid-based surfactants-do they deserve more attention?, Adv Colloid Interface Sci. 222 (2015) 79-91. PMid:25846628; DOI:10.1016/j.cis.2014.10.013

12. Infante, M. R., Perez, L., Pinazo, A., Clapes, P., Moran, M. C., Angelet, M., Garcia, M. T. and Vinardell, M. P.: Amino acid-based surfactants, C R Chim. 7 (2004) 583-592. DOI:10.1016/j.crci.2004.02.009

13. Joondan, N., Jhaumeer-Laulloo, S. and Caumul, P.: Amino-acids: Building blocks for the synthesis of greener amphiphiles, J Disper Sci Technol. 39 (2018) 1550 - 1564. DOl:10.1080/01932691.2017.1421085

14. Ohta, A., Toda, K., Morimoto, Y., Asakawa, T. and Miyagishi, S.: Effect of the side chain of $\mathrm{N}$-acyl amino acid surfactants on micelle formation: an isothermal titration calorimetry study, Colloid Surf A Physicochem Eng Asp. 317 (2008) 316-322. DOI:10.1016/..colsurfa.2007.10.028

15. Sreenu, M. Nayak, R. R. Prasad, R. B. N. and Sreedhar, B.: Synthesis, surface and micellar properties of sodium N-oleoyl amino acids, Colloid Surf A Physicochem Eng Asp. 449 (2014) 74-81. DOl:10.1016/j.colsurfa.2014.02.037

16. Bourkaiba, M. C., Delaunaya, S., Framboisiera, X., Hôtelb, L., Aigleb, B., Humeaua, C., Guiavarc'ha, Y. and Chevalota, I.: N-acylation of L-amino acids in aqueous media: Evaluation of the catalytic performances of Streptomyces ambofaciens aminoacylases, Enzyme Microb Technol. 137 (2020) 109536. PMid:32423673; DOl:10.1016/j.enzmictec.2020.109536

17. Deepak, R. N. V. K. and Sankararamakrishnan, R.: Unconventional N-H...N Hydrogen Bonds Involving Proline Backbone Nitrogen in Protein Structures, Biophys J. 110 (2016) 1967-1979. PMid:27166805; DOI:10.1016/j.bpj.2016.03.034

18. Joondan, N., Caumul, P. and Jhaumeer Laulloo, S.: Investigation of the physicochemical and biological properties of proline-based surfactants in single and mixed surfactant systems, J Surfactants Deterg. 20 (2016) $103-115$. DOI: 10.1007/s11743-016-1895-7

19. Sreenu, M., Prasad, R. B. N., Sujitha, P. and Chityala, G. K.: Synthesis, surface active properties and cytotoxicity of sodium N-acyl prolines, J Oleo Sci. 64 (2015) 1175-1184. PMid:26521810; DOI: 10.5650/jos.ess 15077

20. Sreenu, M., Rao, B. V. S. K., Prasad, R. B. N., Sujitha, P. and Chityala, G. K.: Synthesis, surface and biological properties of sodium $\mathrm{N}$-acyl isoleucines, Eur J Lipid Sci Tech. 116 (2013) 193-206. DOI:10.5650/jos.ess 15077

21. Joondan, $N$, Jhaumeer Laulloo, S. and Caumul, P.: A study of the antibacteria activity of I-Phenylalanine and I-Tyrosine esters in relation to their CMCS and their interactions with 1,2-dipalmitoyl-sn-glycero-3-phosphocholine, DPPC as model membrane. Microbiol Res, 169 (2014) 675-685. PMid:24667307; DOI:10.1016/j.micres.2014.02.010

22. Joondan, N., Jhaumeer Laulloo, S., Caumul, P., Marie, D.E.P., Roy, P. and Hos ten, E.: Synthesis, physicochemical properties and membrane interaction of novel quaternary ammonium surfactants derived from I -Tyrosine and I -DOPA in relation to their antimicrobial, hemolytic activities and in vitro cytotoxicity, Colloid Surf A Physicochem Eng Asp. 511 (2016) 120- 134. DOI:10.1016/j.colsurfa.2016.09.050

23. Pukale, D. D., Bansode, A. S., Pinjari, D. V., Kulkarni, R. R. and Sayed, U.: Application of Silicone Surfactant Along with Hydrocarbon Surfactants to Textile Washing for the Removal of Different Complex Stains, J Surfactants Deterg. 20 (2016) 287-295. DOI:10.1007/s11743-016-1901-0
24. Gasteiger, J. and Marsili, M.: A new model for calculating atomic charges in molecules, Tetrahedron Lett. 19 (1978) $3181-3184$ DOI:10.1016/S0040-4039(01)94977-9

25. O'Boyle, N. M., Banck, M., James, C. A., Morley, C., Vandermeersch, T. and Hutchison, G. R.: Open Babel: An open chemical toolbox, J Cheminformatics. 3 (2011) 1-14. PMid:21982300; DOI:10.1186/1758-2946-3-33

26. Morris, G. M., Huey, R., Lindstrom, W., Sanner, M. F., Belew, R. K., Goodsell, D. S. and Olson, A. J.: AutoDock4 and AutoDockTools4: Automated docking with selective receptor flexibility, J Comput Chem. 30 (2009) 2785-2791. PMid:19399780; DOI:10.1002/jcc.21256

27. Laskowski, R. A. and Swindells, M. B.: LigPlot+: Multiple Ligand-Protein Interaction Diagrams for Drug Discovery, J Chem Inf Model. 51 (2011) 27782786. PMid:21919503; DOI:10.1021/ci200227u

28. Dave, $A ., Y$, $A$. and Singh, $H$.: Structural and interfacial characteristics of oil bodies in coconuts (Cocos nucifera L.), Food Chem. 276 (2019) 129- 139. PMid:30409575; DOl:10.1016/j.foodchem.2018.09.125

29. Rodriguez-Pulido, A., Casado, A., Munoz-Ubeda, M., Junquera, E. and Aicart, E.: Experimental and Theoretical Approach to the Sodium Decanoate-Dodecanoate Mixed Surfactant System in Aqueous Solution, Langmuir. 26 (2010) 9378-9385. PMid:20462279; DOI:10.1021/la 100373r

30. Vautier-Giongo, C. and Bales B. L.: Estimate of the Ionization Degree of Ionic Micelles Based on Krafft Temperature Measurements, J Phys Chem B. 107 (2003) 5398-5403. DOI:10.1021/jp0270957

31. Johansson, I. and Somasundaran, P.: Evaluation of Decontamination Efficacy of Cleaning Solutions on Stainless Steel and Glass Surfaces Contaminated by 10 Antineoplastic Agents, Handbook for Cleaning/Decontamination of Surfaces. (2007) Amsterdam: Elsevier Science. DOI:10.1093/annhyg/mes087

32. Honisch, M.; Stamminger, R. and Bockmuhl, D. P.: Impact of wash cycle time, temperature and detergent formulation on the hygiene effectiveness of domestic laundering, J Appl Microbiol. 117 (2014) 1787- 1797. PMid:25207988; DOI: $10.1111 /$ jam.12647

33. Phan, T.; Witthayapanyanon, A.; Harwell, J. and Sabatini, D.: MicroemulsionBased Vegetable Oil Detergency Using an Extended Surfactant, J Surfactants Deterg, 13 (2010) 313-319. DOI:10.1007/s11743-010-1184-9

34. Wu, C: Liu, Y. Yang, Y. Zhang, $P \cdot$ : Zhong, W. Wang, $Y \cdot$ Wang, $Q \cdot X U, Y \cdot L i, M$. $L i, X$.; Zheng, M.; Chen, $L$. and $L i, H$.: Analysis of therapeutic targets for SARSCoV-2 and discovery of potential drugs by computational methods, Acta Pharm Sin B. 10 (2020) 766-788. PMid:32292689; DOI:10.1016/j.apsb.2020.02.008

35. Wan, Y.; Shang, J.; Graham, R.; Baric, R. and Li, F.: Receptor Recognition by the Novel Coronavirus from Wuhan: an Analysis Based on Decade-Long Structural Studies of SARS Coronavirus, Journal of Virology. 94 (2020) 1 -9. PMid:31996437; DOI:10.1128/JVI.00127-20

36. Madsen, J.; Pihl, R.; Møller, A.; Madsen, A.; Otzen, D. and Andersen, K.: The anionic biosurfactant rhamnolipid does not denature industrial enzymes, Front Microbiol. 6 (2015) 1- 13. DOI:10.3389/fmicb.2015.00292

37. Wells, J. A., and Estell, D. A.: Subtilisin: an enzyme to be engineered, Trends Biochem Sci. 13 (1988) 291 -297. DOI: 10.1016/0968-0004(88)90121-1

38. Bryan, P. N., Rollence, M. L., Pantoliano, M. W., Wood, J., Finzel, B. C., Gilliland, G. L., Howard, A.J. and Poulos, T. L.: Protease of enhanced stability. Characterization of a thermostable variant of subtilisin, Proteins I. (1986) 326-334. PMid:3329733; DOI: 10.1002/prot.340010406

39. Betzel, C., Klupsch, S., Papendorf, G., Hastrup, S., Branner, S. and Wilson, K. S. Crystal structure of the alkaline proteinase Savinase from Bacillus lentus at 1.4 Ao resolution, J Mol Biol. 223 (1992) 427-445. DOI:10.1016/0022-2836(92)90662-4

Received: 04. 04. 2020

Revised: 17. 06. 2020

\section{Bibliography}

DOI 10.3139/113.110705

Tenside Surf. Det.

57 (2020) 5; page $361-374$

(c) Carl Hanser Verlag GmbH \& Co. KC

ISSN 0932-3414

\section{Correspondence address}

Prof. Dr. Sabina Jhaumeer Laulloo

Department of Chemistry

Faculty of Science

University of Mauritius

Réduit

Mauritius

Fax: (230)465 6928

E-Mail: sabina@uom.ac.mu 


\section{The authors of this paper}

Dr. Nausheen Joondan is currently a PostDoctoral Fellow at the Department of Chemistry, University of Mauritius. She obtained her Ph.D (Organic Chemistry) in 2018 from the University of Mauritius. She has published over 10 research papers.

Miss Harsha Devi Angundhooa received her B.Sc. (Hons) Chemistry degree in 2019 from the University of Mauritius. She was working on coconut oil based surfactants as her final dissertation project.

Professor Minu Gupta Bhowon is a Professor at the Department of Chemistry, Faculty of Science, University of Mauritius. She obtained her PhD in 1989 from Indian Institute of Technology, Kanpur, India. She has more than 25 years of teaching experience in group chemistry, coordination chemistry and bioinorganic chemistry.
Her research interests include coordination chemistry, bioinorganic, catalysis and natural product chemistry. She has published more than 50 research articles in leading journals.

Dr. Prakashanand Caumul is a Senior Lecturer at the Department of chemistry, University of Mauritius. He obtained his Ph.D. (2002) from the University College London, UK. His research interests are in the field of Organic/Surfactant Chemistry. His work has involved Synthesizing Novel Surfactants and investigating their Catalytic and Biological properties for potential use in the Pharmaceutical and Cosmetic industry. He has published over 15 research papers.

Professor Sabina Jhaumeer Laulloo is currently a Professor in Organic Chemistry at the Department of Chemistry, University of Mauritius. She obtained her Ph.D (1996) from the University of Mauritius. Her research interests are in the field of Organic/Bioorganic chemistry/Forensic Science. She has published over 70 research papers. 